\title{
Migration of rat peritoneal cells after intra-abdominal infection with Bacteroides fragilis and Escherichia coli
}

\author{
Willem R. Verweij, ${ }^{*}$ Ferry Namavar, Willem F. Schouten, Johannes de GraAfF and \\ DAVID M. MacLAREN
}

Department of Medical Microbiology, School of Medicine, Vrije Universiteit, Van der Boechorststraat 7 , 1081 BT Amsterdam, The Netherlands

(Received 31 December 1992; revised 16 March 1993; accepted 24 March 1993)

\begin{abstract}
A fibrin clot model for intra-abdominal abscess formation was used to study the migratory properties of peritoneal cells from rats during the early stages of infection. Peritoneal cells and fibrin clot remnant were harvested $6 \mathrm{~h}$ after implantation of a sterile, singly infected (Escherichia coli or Bacteroides fragilis) or mixed infected (E. coli and B. fragilis) fibrin clot. Histological study of fibrin clots, removed $6 \mathrm{~h}$ after implantation, showed a deeper infiltration by host cells of $B$. fragilis infected clots compared to the others. This difference in infiltration by peritoneal cells was not due to differences in fibrinolytic activity of the bacterial strains. Differential cell counts of the peritoneal cells from rats implanted with sterile, singly and mixed infected fibrin clots showed distribution over subpopulations to be independent of the bacterial content of the infected clots used. In vitro migration assays showed no significant differences in migration by peritoneal cells from rats implanted with clots containing a different bacterial composition. Since $\boldsymbol{B}$. fragilis infected fibrin clots were more deeply infiltrated by host defence cells than the other clots, and only mixed infected clots led to persistent abscesses in this model, we conclude that local conditions within the fibrin matrix rather than intrinsic cellular capacities of the host cells are important for the process of abscess formation.
\end{abstract}

\section{Introduction}

Intra-abdominal abscesses are a result of an inflammatory response in which polymorphonuclear leucocytes (PMNL) play a key role. The formation of fibrous adhesions containing bacteria and the failure of the lymphatic system, indigenous macrophages and recruited PMNL to cope with the contamination, eventually leads to the formation of a circumscribed collection of pus. In our previous study we focused on the phagocytic and killing capacities of host cells during the early stage of mixed intra-abdominal infection (Verweij et al., 1993). The ability of leucocytes to migrate towards and into an injured or contaminated site is another essential step in the process of abscess formation. Studies of chemotaxis and random migration of host cells in response to bacterial infection frequently use in vitro assays and peripheral human leucocytes from healthy donors. Using this approach an inhibition of chemotaxis by bacterial products was observed (Rotstein et al., 1985, 1986;

*Author for correspondence. Tel. 20 5483955; fax 206447151.

Abbreviations: FCS, foetal calf serum; mAb, monoclonal antibody; PMNL, polymorphonuclear leucocytes.
Namavar et al., 1987). Solomkin et al. (1981) used PMNL from patients with intra-abdominal infection and showed that these cells were depressed in their chemotaxis and spontaneous migration. In the study presented here we investigated in vivo and in vitro migratory abilities of the peritoneal cell population actually present during the early stages of single and mixed Escherichia coli/Bacteroides fragilis infections. We used a rat fibrin clot model for intra-abdominal abscess formation, which in previous studies led only to persistent abscesses when both bacterial species were present (Verweij et al., 1991).

In our previous studies, using this model, we defined a decisive moment in abscess formation, $6 \mathrm{~h}$ after clot implantation. This point was marked by an increase in viable counts of $B$. fragilis in the mixed infected clot after an initial decrease, whereas in the $B$. fragilis singly infected clot there was a clear decrease. In the latter case both bacteria and fibrin clot were removed by host defences within $24 \mathrm{~h}$, in contrast to the persistent abscesses that resulted from mixed infected clots. We therefore focused our attention on $6 \mathrm{~h}$ after clot implantation when studying migratory abilities of peritoneal cells. This was done by determining the infiltration zone of the clot remnant by host cells and the in vitro 
capacity of peritoneal cells to migrate towards a synthetic chemoattractant.

We also studied the possibility of fibrinolytic activity by $B$. fragilis and $E$. coli. This activity might have led to degradation of the fibrin clot matrix and thereby eased infiltration by host cells.

\section{Methods}

Bacterial strains. Both the Bacteroides fragilis (BE1) and the Escherichia coli (EB1), serotype O8:K43) strain used in the present study are clinical isolates and have been used in previous studies (Verweij et al., 1991; Otto et al., 1988; Namavar et al., 1987; VerweijVan Vught et al., 1986). Techniques of storage, growth conditions and ingredients of the minimal growth medium (MM-medium) have been described previously (Namavar et al., 1983). For inoculation of the fibrin clots and killing experiments late-exponential $(16 \mathrm{~h})$ cultures were pelleted by centrifugation, washed and resuspended in Hank's Buffered Salts solution (HBSS, Gibco) supplemented with $0.5 \mathrm{mg}^{-1}$ cysteine hydrochloride $1^{-1}$ for $B$. fragilis and buffered saline $(0.9 \%, \mathrm{pH} 7.4)$ for $E$. coli. The bacterial concentrations of the suspensions were adjusted to $1-2 \times 10^{9}$ c.f.u. $\mathrm{ml}^{-1}$ for $B$. fragilis and $1-2 \times 10^{6}$ c.f.u. $\mathrm{ml}^{-1}$ for $E$. coli. For measurement of fibrinolytic activity $50 \%(\mathrm{v} / \mathrm{v})$ foetal calf serum (FCS) diluted 1:1 with PBS (137 mM-NaCl, 2.68 mM-KCl, $6.46 \mathrm{mM}-\mathrm{Na}_{2} \mathrm{HPO}_{4} .2 \mathrm{H}_{2} \mathrm{O}$ ), $1.47 \mathrm{mM}-\mathrm{KH}_{2} \mathrm{PO}_{4}$ ) was used together with the standard media for culturing EB1 and BE1. A fresh isolate of Enterococcus faecalis as cultured on Lab-Lemco Broth (Oxoid) and MM-medium and Porphyromonas gingivalis HG 66 (=W83, H. N. Shah) in phosphate-buffered basic medium (BMP; Verweij-Van Vught et al., 1986) supplemented with haemin $\left(5 \mathrm{mg} \mathrm{l}^{-1}\right)$ and menadione $\left(2 \mathrm{mg} \mathrm{l}^{-1}\right)(\mathrm{h} / \mathrm{m})$

Incorporation of bacteria into the fibrin clot. Sterile and bacterially infected fibrin clots were made as previously described (Verweij et al., 1991). Briefly, $100 \mu 1$ of the bacterial suspensions or the appropriate buffer were added to $1.4 \mathrm{ml}$ of human fibrinogen (Sigma; $2 \mathrm{mg} \mathrm{m}^{-1}$ in calcium- and magnesium-free PBS). After gently mixing the tubes, $200 \mu \mathrm{l}$ thrombin (Sigma; $30 \mathrm{NIH}$ units $\mathrm{ml}^{-1}$ in sterile distilled water) was added to catalyse fibrin clot formation. Both the harvesting of bacteria and the incorporation into the fibrin clot were performed under normal atmospheric conditions, maximal time between cell harvesting and implantation of the fibrin clots was $2.5 \mathrm{~h}$.

Animals and surgical procedure. Male Wistar rats (Harlan CPB, Zeist, The Netherlands) weighing $200 \mathrm{~g}$ on arrival were allowed to adapt for a week before operation. During this period food and water were provided ad libitum. Fibrin clots, either sterile, singly or mixed infected ones, were implanted intra-peritoneally (i.p.) via a $2-3 \mathrm{~cm}$ midline incision made under ether anaesthesia. The incision was closed in two layers with four sutures each. Total anaesthesia time was less than 10 min (Verweij et al., 1991).

Preparation and characterization of the peritoneal cell population. The animals were killed by inhalation of $\mathrm{CO}_{2} 6 \mathrm{~h}$ after implantation of the fibrin clot. Peritoneal cells were harvested by lavage with $5 \mathrm{ml}$ buffered saline supplemented with $0 \cdot 2 \%$ bovine serum albumin (BSA) and kept on ice until used. After complete opening of the peritoneal cavity the remnant of the fibrin clot was taken out, weighed and either frozen in liquid $\mathrm{N}_{2}$ or washed once and treated with $1 \mathrm{ml}$ trypsin (Sigma; $1000 \mathrm{U} \mathrm{ml}^{-1}$ in $50 \mathrm{~mm}$-Tris/ $\mathrm{HCl}, \mathrm{pH} \mathrm{7 \cdot 3).} \mathrm{Peritoneal} \mathrm{cell} \mathrm{samples} \mathrm{were}$ counted in a Bürker chamber and viability was determined by trypan blue exclusion. The total numbers of cells were calculated by correcting for the volume that could be withdrawn from the peritoneal cavity. Differential cell counts were made from cytocentrifuge preparations
(Shandon Southern Instruments Ltd) stained with May-Grünwald Giemsa in which 500 cells were counted.

Fibrin clot infltration. For histological assessment 8-12 $\mu \mathrm{m}$ sections of the frozen fibrin clots were air-dried and stored overnight on silica gel. Fibrin clot sections were stained with May-Grünwald and Gram stain and infiltration zones of the peritoneal cells were scored semiquantitatively.

Further characterization of the infiltrating cell population was done with monoclonal antibody (mAb) ED1 against rat macrophages, kindly provided by Dr C. D. Dijkstra (Department of Cell Biology, Faculty of Medicine, Vrije Universiteit Amsterdam, The Netherlands). $\mathrm{mAb}$ ED1 has been shown to react with the total monocyte population (Dijkstra et al., 1985; Beelen et al., 1987). Macrophages expressing the antigen recognized by $\mathrm{mAb} E D 1$ were detected by an immunoperoxidase procedure in ultrathin sections with $3,3^{\prime}$-diaminobenzidinetetrahydrochloride (DAB) (Sigma) as chromogen. Briefly, preparations, dried overnight on silica gel, were fixed in $1 \%(\mathrm{v} / \mathrm{v})$ formalin in acetone, washed with PBS and incubated for 30-60 min with $\mathrm{mAb}$ diluted in PBS supplemented with $0.2 \%$ (w/v) BSA. After being washed three times with PBS, samples were incubated with rabbit antimouse IgG horseradish peroxidase (DAKO) diluted in PBS with $0.2 \% \mathrm{BSA}$ and $1 \%$ normal rat serum for $30 \mathrm{~min}$. Samples were washed again three times and incubated for $15 \mathrm{~min}$ with the chromogen DAB $\left(0.5 \mathrm{mg} \mathrm{ml}^{-1}\right.$ in $\left.0.05 \mathrm{M}-\mathrm{Tris} / \mathrm{HCl}, \mathrm{pH} 7.6\right)$ and $0.03 \%(\mathrm{v} / \mathrm{v}) \mathrm{H}_{2} \mathrm{O}_{2}$. After three further wash steps the samples were counterstained with haematoxylin for $1 \mathrm{~min}$. Sometimes an additional incubation in $0.5 \% \mathrm{CuSO}_{4}$ was used to 'amplify' the staining.

In vitro migration. The chemotaxis of the peritoneal cells was determined by chemotactic assay in agarose as previously described (Namavar et al., 1984). The media contained $1.2 \%(\mathrm{w} / \mathrm{v})$ agarose, $10 \mathrm{ml} 10 \times \mathrm{TC}$ medium 199 (Difco), $1 \mathrm{ml} 7.5 \%$ (w/v) sodium bicarbonate, $10 \mathrm{ml}$ inactivated new-born calf serum and $79 \mathrm{ml}$ distilled water. A $10 \mathrm{ml}$ volume of the agarose medium was put into tissue culture plates $(60 \times 15 \mathrm{~mm}$, Falcon). Four series of three wells, $3 \mathrm{~mm}$ in diameter and $3 \mathrm{~mm}$ apart, were punched in the agarose gel. The centre well of each three-well series received $10 \mu$ peritoneal cell suspension $\left(10^{7}\right.$ cells $\mathrm{ml}^{-1}$ in TC medium 199), the outer well received $10 \mu \mathrm{l}$ $2 \times 10^{-7}$ M-f-Met-Leu-Phe in PBS and the inner well control medium. The plates were incubated at $37^{\circ} \mathrm{C}$ in a humidified atmosphere containing $5 \%(\mathrm{v} / \mathrm{v}) \mathrm{CO}_{2}$ in air. After $3 \mathrm{~h}$ of incubation the plates were flooded with $5 \mathrm{ml}$ methanol $(99 \%, \mathrm{v} / \mathrm{v})$ for $30 \mathrm{~min}$ and then after decanting the methanol they were flooded with the same volume of $4 \%$ (v/v) formalin for another $30 \mathrm{~min}$. The agarose was removed and cells stained with Giemsa stain. Migration was scored under a microscope (total magnification $25 \times$ ) and chemotaxis was expressed as the difference between directed migration and random migration.

Statistical analysis of the data was performed using Student's $t$-test.

Fibrinolytic activity. Bovine fibrinogen (Sigma, $12 \mathrm{mg} \mathrm{ml}^{-1}$ ) was dissolved in PBS without $\mathrm{Ca}^{2+}$ and $\mathrm{Mg}^{2+}$ (Gibco) and sterilized by UV irradiation for $30 \mathrm{~min}$. Thrombin was suspended in sterile distilled water to a concentration of $30 \mathrm{NIH}$ units $\mathrm{ml}^{-1}$. Top layers were made by adding $200 \mu \mathrm{l}$ thrombin to $2.8 \mathrm{ml}$ fibrinogen and, after being gently mixed, were poured over blood-agar plates. Plates were allowed to stand for $30 \mathrm{~min}$ under UV irradiation and kept at $4{ }^{\circ} \mathrm{C}$ until used. Bacterial suspensions and culture supernatant $(5 \mu \mathrm{l})$ were tested for fibrinolytic activity after $48 \mathrm{~h}$ aerobic or anaerobic incubation at $37^{\circ} \mathrm{C}$. Fibrinolytic activity was recorded as a clear zone around the inoculum spot. Results were expressed on a semi-quantitative scale.

Detection of capsules. Capsules were detected by negative staining with Indian ink. A drop of a $16 \mathrm{~h}$ broth culture (late exponential phase) was mixed with a drop of $10 \%(\mathrm{w} / \mathrm{v})$ glucose and a drop of Indian ink on a microscope slide. This was spread over the slide, allowed to airdry, fixed with ethanol and stained with ammonium crystal violet. Wet 
Table 1. Parameters of clot remnant and cellular host defence of the rat peritoneal cavity $6 \mathrm{~h}$ after implantation of the fibrin clot

The implanted clots were inoculated with $1-2 \times 10^{5}$ c.f.u. $E$. coli and/or $1-2 \times 10^{8}$ c.f.u. B. fragilis. The results are means or means \pm SD of three experiments except in the case of the clot mass which is the mean \pm SD of six experiments.

\begin{tabular}{|c|c|c|c|c|c|}
\hline \multirow[b]{2}{*}{ Fibrin clot } & & \multicolumn{4}{|c|}{ Type of fibrin clot } \\
\hline & & Mixed & E. coli & B. fragilis & Sterile \\
\hline $\begin{array}{l}\text { c.f.u. present } \\
\text { in clot }\end{array}$ & $\begin{array}{l}\text { E. coli } \\
\text { B. fragilis }\end{array}$ & $\begin{array}{l}3-7 \times 10^{7} \\
2-4 \times 10^{7}\end{array}$ & $\begin{array}{c}1-3 \times 10^{7} \\
-\end{array}$ & $2-3 \times 10^{7}$ & - \\
\hline $\begin{array}{r}\text { Clot mass on } \\
\text { isolation (g) }\end{array}$ & & $0.15 \pm 0.03$ & $0 \cdot 21 \pm 0.02$ & $0.13 \pm 0.02$ & $0.24 \pm 0.03$ \\
\hline \multirow{2}{*}{$\begin{array}{l}\text { 'Free' peritoneal } \\
\text { cell population* }\end{array}$} & Total & $6.9 \times 10^{7}$ & $5.2 \times 10^{7}$ & $7.2 \times 10^{7}$ & $5.0 \times 10^{7}$ \\
\hline & $\begin{array}{l}\% \text { PMNL } \\
\% \text { MO } \\
\% \text { EOS } \\
\% \text { Rest }\end{array}$ & $\begin{array}{r}68 \pm 5 \\
29 \pm 4 \\
3 \pm 2 \\
0 \pm 1\end{array}$ & $\begin{array}{r}61 \pm 4 \\
34 \pm 4 \\
4 \pm 2 \\
1 \pm 1\end{array}$ & $\begin{array}{r}72 \pm 4 \\
26 \pm 3 \\
2 \pm 1 \\
0 \pm 1\end{array}$ & $\begin{array}{r}51 \pm 8 \\
41 \pm 6 \\
6 \pm 2 \\
2 \pm 1\end{array}$ \\
\hline $\begin{array}{l}\text { Peritoneal cells } \\
\text { present in fibrin } \\
\text { clot }\end{array}$ & $\begin{array}{l}\% \text { PMNL } \\
\% \text { MO } \\
\% \text { EOS } \\
\% \text { Rest }\end{array}$ & $\begin{array}{r}74 \pm 4 \\
24 \pm 4 \\
2 \pm 1 \\
0 \pm 1\end{array}$ & $\begin{array}{r}67 \pm 8 \\
32 \pm 8 \\
1 \pm 1 \\
0 \pm 1\end{array}$ & $\begin{array}{r}79 \pm 4 \\
19 \pm 4 \\
2 \pm 1 \\
0 \pm 0\end{array}$ & $\begin{array}{r}55 \pm 6 \\
41 \pm 6 \\
3 \pm 2 \\
1 \pm 1\end{array}$ \\
\hline $\begin{array}{l}\text { Infiltration zone } \\
\text { by host } \\
\text { peritoneal cells } \dagger\end{array}$ & & +++ & ++ & ++++ & + \\
\hline
\end{tabular}

* Total number of host defence cells in peritoneal cavity. PMNL, PMNL minus eosinophils; MO, macrophages; EOS, eosinophils; Rest, mast cells and lymphocytes.

$\dagger$ Light microscopical (semi-quantitative) infiltration score, verified by multiple experiments. + , minimal infiltration; ++ , slight infiltration; +++ , moderate infiltration; ++++ , deep infiltration.

suspensions were also made by mixing the bacterial suspension, glucose and ink on a slide, placing a coverslip on the mixture and blotting off the excess. The slides were examined by light microscopy.

\section{Results}

\section{Peritoneal cell population}

The percentages and absolute numbers of the cell types present in the peritoneal cavity at $6 \mathrm{~h}$ after implantation of the different kinds of fibrin clots are shown in Table 1. This Table also shows the percentages of the cell types present in the fibrin clots $6 \mathrm{~h}$ after implantation.

In bacterially infected clots the population of infiltrating cells seems a fair reflection of the 'free' cells in the peritoneum. The percentage of PMNL, however, is somewhat higher especially in the case of $B$. fragilis infected fibrin clots.

\section{Fibrin clot infiltration by peritoneal cells}

Figs $1(a-d)$ are light microscope photographs of May-Grünwald Giemsa-stained ultrathin sections of the fibrin clots which were removed $6 \mathrm{~h}$ after implantation. These photographs show the infiltration zone by host defence cells of the fibrin matrix. As can be seen infiltration by host cells of sterile clot matrix (Fig. $1 a$ ) is minimal. Fibrin clots infected with a pure culture of $E$. coli showed a slight infiltration zone (Fig. $1 b$ ). A deeper zone of infiltration by host cells was seen in clots infected with a combination of $E$. coli and $B$. fragilis (Fig. 1c). The deepest infiltration zone was seen in the case of a single $B$. fragilis inoculum (Fig. $1 d$ ).

Further characterization of the cell population infiltrating the fibrin clot using $\mathrm{mAb} E D 1$, indicated that PMNL, predominantly neutrophils, penetrated deepest whereas macrophages were located as a layer on the periphery (results not shown).

\section{In vitro migration}

To find out whether differences in fibrin clot infiltration were due to different migratory capacities of peritoneal cells as a consequence of different bacterial inocula in the clots, peritoneal cells of rats implanted with sterile, singly, and mixed infected $B$. fragilis and $E$. coli fibrin clots were assayed in vitro. Table 2 shows the migratory capacity of the cells from rats implanted with different kinds of bacterial infected clots. These results show that 

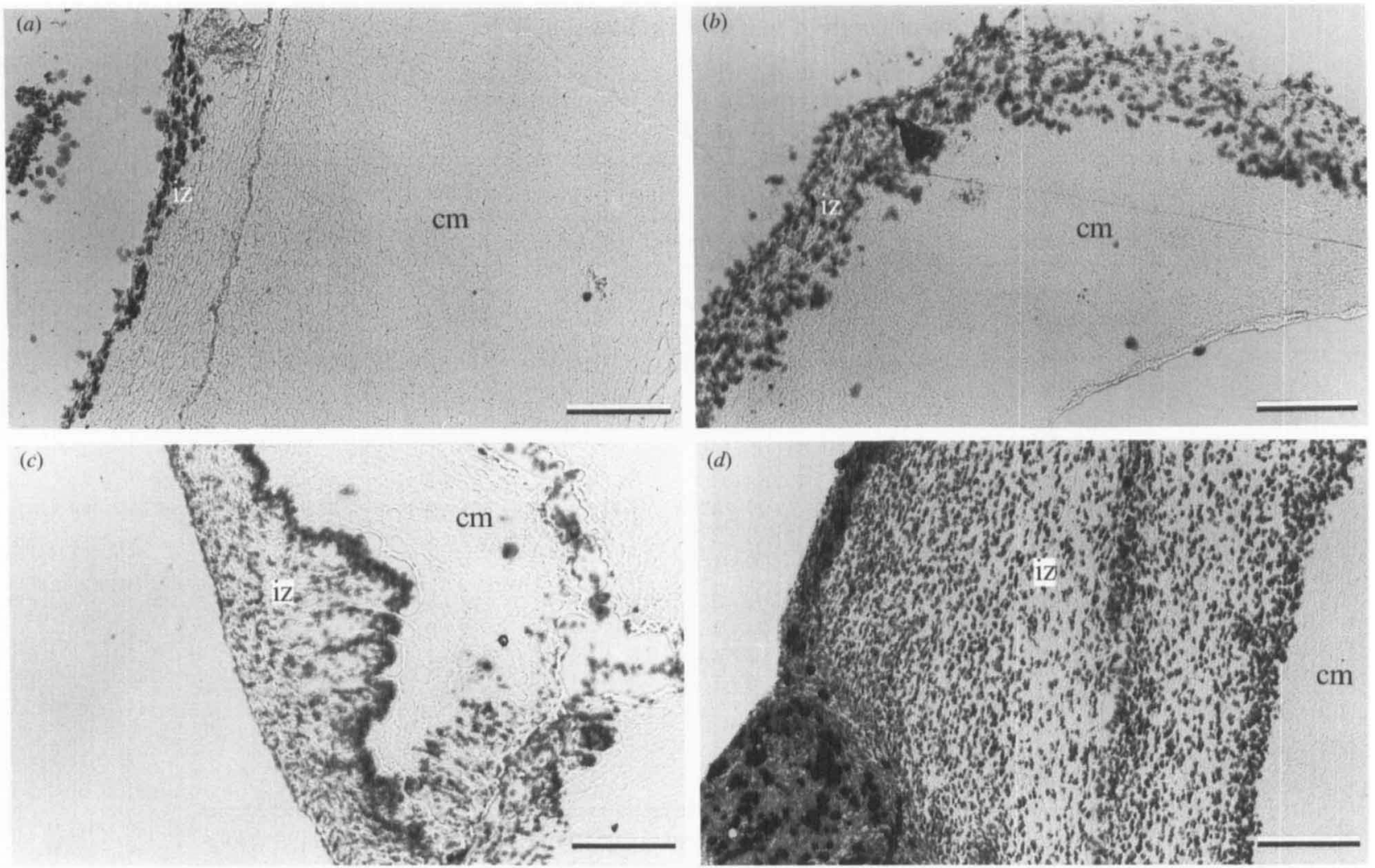

Fig. 1. May-Grünwald-stained ultrathin sections $(12 \mu \mathrm{m})$ of fibrin clots removed $6 \mathrm{~h}$ after implantation. Clots infected with: (a), nothing (sterile clot); (b), E. coli $\left(1-2 \times 10^{5}\right.$ c.f.u. $) ;(c)$, E. coli $\left(1-2 \times 10^{5}\right.$ c.f.u. $)+B$. fragilis $\left(1-2 \times 10^{7}\right.$ c.f.u. $)$ (mixed infected clot); (d), B. fragilis $\left(1-2 \times 10^{7}\right.$ c.f.u. $) . \mathrm{cm}$, Clot matrix; iz, infiltration zone. Bars, $50 \mu \mathrm{m}$.

Table 2. In vitro migration of peritoneal cells towards a synthetic chemoattractant

Cells were isolated from rats $6 \mathrm{~h}$ after implantation of the fibrin clot. The chemoattractant was $2 \times 10^{-7} \mathrm{M}-\mathrm{f}-\mathrm{Met}-\mathrm{Leu}-\mathrm{Phe}$. Values are expressed as mean \pm SE of five experiments.

\begin{tabular}{lll}
\hline \hline \multicolumn{1}{c}{$\begin{array}{c}\text { Bacteria present } \\
\text { in fibrin clot }\end{array}$} & $\begin{array}{c}\text { Chemotactic } \\
\text { difference* }\end{array}$ \\
\hline B. fragilis & $\left(1-2 \times 10^{8}\right)$ & $1.5 \pm 0.20$ \\
+ E. coli & $\left(1-2 \times 10^{5}\right)$ & $1.8 \pm 0.25$ \\
E. coli & $\left(1-2 \times 10^{5}\right)$ & $1.6 \pm 0.30$ \\
B. fragilis & $\left(1-2 \times 10^{8}\right)$ & 1.6 \\
None (sterile clot) & $1.3 \times 0.15$ \\
\hline
\end{tabular}

* Chemotactic difference expressed in $\mathrm{mm}$ as the difference between migration in response to f-Met-Leu-Phe and random migration.

the observed in vivo differences in clot infiltration are not reflected in significant differences in in vitro migration.

\section{Fibrinolytic activity}

To find out whether intrinsic fibrinolytic activity of the micro-organisms contributes to the differences in clot infiltration a fibrinolytic plate-assay was carried out. The results summarized in Table 3 show that neither
B. fragilis nor $E$. coli demonstrated any cell-bound or excreted fibrinolytic activity under the growth conditions tested. P. gingivalis HG 66 and Ent. faecalis, which were used as positive controls, gave clear zones of more than 5 and $10 \mathrm{~mm}$ in diameter respectively.

\section{Capsule staining}

Both the $B$. fragilis (BE1) and the E. coli (EB1) strains used, possessed a large capsule: small numbers of uncapsulated cells were seen in both air-dried and wet preparations (up to $\pm 5 \%$ in $E$. coli preparations and $\pm 15 \%$ in $B$. fragilis preparations).

\section{Discussion}

Several aspects of host defence during mixed intraabdominal infection and abscess formation have been studied by different groups using various in vivo and in vitro models (Weinstein et al., 1974; Hagen et al., 1983; Nulsen et al., 1983; Ahrenholz \& Simmons, 1980; Onderdonk et al., 1989). Special attention has been given to the phenomenon of pathogenic synergy by $B$. fragilis and $E$. coli. In this study we focused our attention on the 
Table 3. Fibrinolytic activity in bacterial suspensions and culture supernatant $(5 \mu l)$ after $48 \mathrm{~h}$ incubation at $37^{\circ} \mathrm{C}$ in various media

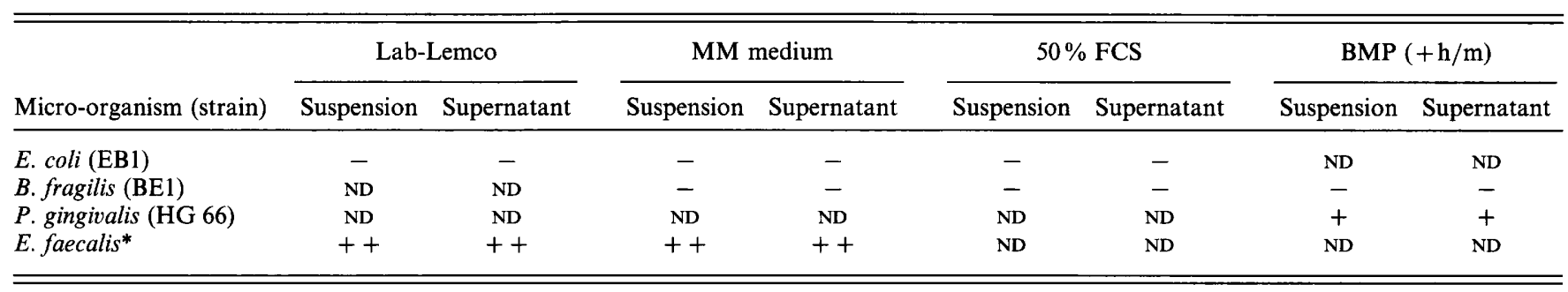

- , No clear zone around application spot or diameter increase $<1 \mathrm{~mm} ;+$, increase of application zone diameter between 1 and $10 \mathrm{~mm} ;++$, increase of application zone diameter $>10 \mathrm{~mm}$. ND, Not determined.

*Fresh isolate.

early stages of infection, both mixed and single, and the capacity of host defence cells to migrate towards the site of infection.

We used an animal model in which bacterial infected fibrin clots were implanted i.p. in rats. Persistent abscesses only formed when both bacterial species were present whereas singly infected fibrin clots with $E$. coli, as the inoculum used, led to abscesses that were cleared within $10 \mathrm{~d}$. B. fragilis alone was rapidly removed without abscess formation (Verweij et al., 1991). Bacterial interference with recruitment and mobility of cellular host defence may explain these differences.

Results of in vitro studies on the effect of $E$. coli and $B$. fragilis on chemotaxis of human peripheral PMNL characterized $B$. fragilis as a poor inducer, even able to inhibit the chemotaxis of PMNL towards $E$. coli (Namavar et al., 1984, 1987; Rotstein et al., 1986). These data were partly explained by an inhibitory or even leucotoxic effect of short chain fatty acids, in particular by succinate, produced by $B$. fragilis (Rotstein et al., $1985,1986,1987)$. The purulence of clinical mixed infections with $B$. fragilis and the profound infiltration by peritoneal cells of $B$. fragilis infected fibrin clots in this model which has a close resemblance to the clinical situation, throws doubts on the in vivo significance of these earlier findings.

The migration of peritoneal cells in the fibrin matrix during the first $6 \mathrm{~h}$ after implantation is much greater in the case of $B$. fragilis infected clots than $E$. coli or mixed infected clots. In the in vivo model these clots do not lead to abscess formation. The PMNL are clearly able to phagocytose and remove $B$. fragilis cells. When the infiltration zones of single $B$. fragilis and mixed infected clots are compared it appears that it is the presence of $E$. coli rather than $B$. fragilis that hampers peritoneal cell infiltration. This may have an important effect on abscess formation. Although $E$. coli alone leads to abscesses, our in vivo results show that $B$. fragilis is necessary for their persistence.

The greater infiltration and smaller weight of the clot remnant at $6 \mathrm{~h}$ after implantation in the case of $B$. fragilis infected clots could also result from enzymic breakdown of the fibrin clot matrix leading to a more readily penetrated and open structure. Our fibrinolytic assay did not indicate that bacterial enzymes led to alterations in the fibrin matrix. Even under iron-limited conditions during growth in $50 \% \mathrm{FCS}$, which are considered more appropriate to in vivo conditions, neither $B$. fragilis nor $E$. coli gave clear zones on 'fibrin-plates' whereas positive controls ( $P$. gingivalis and Ent. faecalis) did.

Since migration towards a synthetic chemoattractant (f-Met-Leu-Phe) by peritoneal cells from rats implanted with sterile, singly or mixed infected clots did not differ significantly, it seems that the hampering of the migration of peritoneal defence cells seen in vivo resulted more from the local environment in the fibrin clot than from a modification of the chemotactic behaviour of the peritoneal cells.

Another possible explanation for the differences between in vivo and in vitro results could be that different receptors or processes are involved in chemotaxis towards micro-organisms and the synthetic chemoattractant f-Met-Leu-Phe so that there are indeed alterations in chemotactic functions brought about by different bacterial inocula; this seems less likely.

Our results are in contrast to the previous in vitro findings of others as well as of our own group, who found that $B$. fragilis and its metabolites such as succinate seemed to play a key role in frustrating host defence during mixed intra-abdominal infections (Namavar et al., 1984, 1987; Rotstein et al., 1985, 1986, 1987). However, in those studies human peripheral PMNL were used instead of the actual cell population present at the site of infection. The PMNL may very well respond differently from peritoneal cells that are adapted to their own environment. Secondly the in vitro culturing of $E$. coli and $B$. fragilis and the media used may influence the metabolic routes and thereby short chain fatty acid production and concentration in the supernatant. In the model we used, washed bacterial cells are implanted and 
bacterial growth and metabolism in the fibrin clot, during the $6 \mathrm{~h}$ residence, takes place under in vivo conditions. Under these conditions an irreversible effect on the migration of free peritoneal cells by the fatty acids which might have been produced was not detected. However, it is not clear to what extent these cells reflect gut-derived bacteria. Study of bacteria cultured under simulated in vivo conditions, as regards $\mathrm{pH}$ and concentration of nutrients, iron and serum proteins is needed to answer this question.

Our study shows that in this model the role of $B$. fragilis in the initial phase of abscess formation is modest as is its effect on migration of peritoneal cells. It is the presence of $E$. coli that seems to hamper host defence, thereby permitting $B$. fragilis to establish itself. For the persistence of abscesses the presence of $B$. fragilis appears essential. The mechanisms by which $E$. coli interferes with host defence and favours the growth of $B$. fragilis in this model need further investigation.

\section{References}

Ahrenholz, D. H. \& Simmons, R. L. (1980). Fibrin in peritonitis. I. Beneficial and adverse effects of fibrin in experimental $E$. coli peritonitis. Surgery 88, 41-47.

BeElen, R. H. J., Eestermans, I. L., Döpp, E. A. \& Dijkstra, C. D. (1987). Monoclonal antibodies ED1, ED2 and ED3 against rat macrophages: expression of recognized antigens in different stages of differentiation. Transplantation Proceedings XIX, 3166-3170.

Dijkstra, C. D., DöpP, E. A., Joling, P. \& KRAal, G. (1985). The heterogeneity of mononuclear phagocytes in lymphoid organs: distinct subpopulations in the rat recognized by monoclonal antibodies ED1, ED2 and ED3. Immunology 54, 589-599.

HaGen, J. C., Wood, W. S. \& Hashimoto, T. (1983). Experimental intraabdominal abscess formation by Escherichia coli and Bacteroides fragilis. European Journal of Clinical Microbiology 2, 43-49.

Namavar, F., Verweis, A. M. J. J., Bal, M., Van Steenbergen, M. T. J., DE GraAFF, J. \& MACLAREN, D. M. (1983). Effect of anaerobic bacteria on killing of Proteus mirabilis by human polymorphonuclear leukocytes. Infection and Immunity 40, 930-935.

Namavar, F., VerweiJ-Van Vught, A. M. J. J., Vel, W. A. C., Bal,
M. \& Maclaren, D. M. (1984). Polymorphonuclear leukocyte chemotaxis by mixed anaerobic and aerobic bacteria. Journal of Medical Microbiology 18, 167-172.

Namavar, F., VerweiJ-Van Vught, A. M. J. J., Bal, M. \& MaCLAREN, D. M. (1987). Effect of Bacteroides fragilis cellular components on chemotactic activity of polymorphonuclear leucocytes towards Escherichia coli. Journal of Medical Microbiology 24, 119-124.

Nulsen, M. F., Finlay-Jones, J. J., Skinner, J. M. \& McDonald, P. J. (1983). Intra-abdominal abscess formation in mice: quantitative studies on bacteria and abscess-potentiating agents. British Journal of Experimental Pathology 64, 345-353.

Onderdonk, A. B., Cisneros, R. L., Crabb, J. H., Finberg, R. W. \& KASPER, D. L. (1989). Intraperitoneal host cellular responses and in vivo killing of Bacteroides fragilis in a bacterial containment chamber. Infection and Immunity 57, 3030-3037.

Otto, B. R., VerweiJ-VAN Vught, A. M. J. J., VAN DOORN, J. \& MACLAREN, D. M. (1988). Outer membrane proteins of Bacteroides fragilis and Bacteroides vulgatus in relation to iron uptake and virulence. Microbial Pathogenesis 4, 279-287.

Rotstein, O. D., Pruett, T. L., Fieger, V. D., Nelson, R. D. \& Simmons, R. L. (1985). Succinic acid, a metabolic by-product of Bacteroides species, inhibits polymorphonuclear leukocyte function. Infection and Immunity 48, 402-408.

Rotstein, O. D., Pruett, T. L., Sorenson, J. J., Fiegel, V. D., Nelson, R. D. \& Simmons, R. L. (1986). A Bacteroides by-product inhibits human polymorphonuclear leucocyte function. Archives of Surgery 121, 82-88.

Rotstein, O. D., Nasmith, P. E. \& Grinstein, S. (1987). The Bacteroides by-product succinic acid inhibits neutrophil respiratory burst by reducing intracellular $\mathrm{pH}$. Infection and Immunity 55, 864-870.

Solomkin, J. S., Bauman, M. P., Nelson, R. D. \& Simmons, R. L. (1981). Neutrophils dysfunction during the course of intraabdominal infection. Annals of Surgery 194, 9-18.

Verweu, W. R., Namavar, F., Schouten, W. F. \& Maclaren, D. M. (1991). Early events after intra-abdominal infection with Bacteroides fragilis and Escherichia coli. Journal of Medical Microbiology 35, 18-22.

Verweid, W. R., Namavar, F., Schouten, W. F., Kostense, P. P., Pellenkoft, M., De GraAfF, J. \& Maclaren, D. M. (1993). In vitro activity of peritoneal cells from rats after intra-abdominal infection with Bacteroides fragilis and Escherichia coli. Journal of Medical Microbiology 38, 13-18.

Verweij-Van Vught, A. M. J. J., Sparrius, M., Namavar, F., Vel, W. A. C. \& MACLAREN, D. M. (1986). Nutritional requirements of Bacteroides fragilis and Bacteroides vulgatus with reference to iron and virulence. FEMS Microbiology Letters 36, 47-51.

Weinstein, W. M., OnderdonK, A. B., Bartlett, J. G. \& Gorbach, S. L. (1974). Experimental intra-abdominal abscesses in rats: development of an experimental model. Infection and Immunity 10, 1250-1255. 